\title{
DISCOVERY OF NEW ANTITUMORAL AND ANTIBACTERIAL DRUGS FROM BRAZILIAN PLANT EXTRACTS USING HIGH THROUGHPUT SCREENING
}

\author{
Riad Naim Younes, Antonio Drauzio Varella, Ivana Barbosa Suffredini
}

\begin{abstract}
Younes RN, Varella AD, Suffredini IB. Discovery of new antitumoral and antibacterial drugs from brazilian plant extracts using high throughput screening. Clinics. 2007;62(6):763-8.

Plants have played a significant role in the treatment of cancer and infectious diseases for the last four decades. The discovery and introduction to market of paclitaxel, the vinca alkaloids, etoposide, and many antibacterial drugs support drug discovery programs based on natural products. Natural products have been rediscovered as important tools for drug development despite advances in combinatorial chemistry, due to the complex molecular structures able to interact with mammalian cell targets. The Brazilian flora, the most diverse in the world, has become an interesting spot to prospect for new chemical leads or hits due to its species diversity and associated chemical richness. Screening programs have been established in Brazil as a strategy to identify potentially active substances. High throughput screening techniques allow for the analysis of large numbers of extracts in a relatively short period of time, and can be considered one of the most efficient ways of finding new leads from natural products. An updated review of the current status of the biological screening program is presented and recent results from new antitumoral and antibacterial chemical leads are discussed.
\end{abstract}

KEYWORDS: Biodiversity. Screening. Natural Products. Amazon Rain Forest, Atlantic Forest

The absolute number of cancer deaths is declining, according to epidemiological studies in most developed countries. Nonetheless, cancer is still considered a major public health problem, second only to cardiovascular diseases in mortality rates. ${ }^{1}$ Systemic chemotherapy for advanced and metastatic disease has evolved dramatically with the introduction of new drugs and regimens, either as isolated treatment, or in adjuvant settings, associated with surgery or radiation therapy. ${ }^{2}$ Several new molecules have been developed into commercially available drugs that originate from extracts derived from natural resources, such as paclitaxel, the vinca alkaloids and etoposide.

Infections are still considered one of the main causes of human and animal morbidity and consequent mortality. Controlling resistant bacteria is an increasingly challeng-

Laboratório de Extração da Universidade Paulista - UNIP

Email: rnyounes@yahoo.com.br

Received for publication on September 04, 2007

Accepetd for publication on September 04, 2007 ing endeavor and is a major concern for specialists around the world..$^{3-6}$ The introduction of new antibiotics therefore became a matter of public health. Fortunately, research in this area is widespread, and, as for cancer, natural products can be considered one of the main sources of new drugs. Data published in $1997^{7}$ and updated in $2003^{8}$ showed that over $50 \%$ of all new antibiotics approved by the FDA were extracted from natural sources, derived from a natural lead, or synthesized (or semi-synthesized) based on a known natural product.

Natural products still play an important role as a source of new antitumoral and antibacterial leads, despite recent progress in combinatorial chemistry. Although more than 100,000 synthetic compounds originate from combinatorial chemistry at any given time, a high percentage of these products still do not have the specific spatial structure required to interact with mammalian targets. ${ }^{9}$ The design of new anticancer drugs has entered a new era: combinatorial chemistry is now an important tool for the introduction of new drugs into the market. However, the chemical 
diversity found in natural products offers new and original options, adding to the thousands of products obtained from combinatorial chemistry. Compounds isolated from plants, especially small molecules, frequently show biological activities such as inhibition of macromolecular targets, including proteins. On the other hand, even an entire library of synthetic products may fail to show any significant activity because most of these products usually consist of big molecules with no distinctive biological activity. ${ }^{10}$

The effectiveness of drugs such as paclitaxel, docetaxel, etoposide and the vinca alkaloids ${ }^{11}$, together with important antibiotics such as vancomycin and penicillin, reperesent a few examples of the importance of natural products in drug discovery. Moreover, little is known about the pharmacology or phytochemistry of plants and animals representative of the biodiversity found in countries such as Brazil. The number of superior plants is estimated to be between 200,000 and 250,000 species $^{12}$ and only approximately $20 \%$ of the plants have been pharmacologically evaluated. ${ }^{8}$ Brazil contains $20 \%$ of the world's biodiversity, ${ }^{13}$ and over $17 \%$ of the Brazilian biodiversity can be found in the Amazon Rain Forest. ${ }^{14}$ The Atlantic Forest contains approximately $35 \%$ of the world's Angiospermae, and more than $8 \%$ of the Pteridophytae. ${ }^{15}$ In view of this species richness and considering that these forests are currently considered as major areas for conservation ${ }_{2}{ }^{16}$ scientific interest in the potential pharmacological resources in the Brazilian forests has been renewed.

Bioprospection of natural resources using screening procedures is not a new technique; although it has been used for decades, it was implemented in Brazil only recently. The US/NIH National Cancer Institute (NCI) has a large screening program capable of testing 10,000 compounds/ extracts per year. More than 114,000 extracts obtained from 35,000 plant species have already been tested in that program, and only $4 \%$ have shown significant activity. ${ }^{17}$ Presently, the NCI bank of extracts has more than 200,000 extracts from marine and terrestrial plant and animal extracts and isolated compounds. It was through this program that some of the important anticancer drugs were discovered, such as paclitaxel (from Taxus brevifolia Nutt.), camptothecin (Camptotheca acuminata Decne) and podophyllotoxin/etoposide (semi-synthetically obtained) (from Podophyllum peltatum L.), ${ }^{18,19}$ all of which are currently being routinely used in cancer therapy.

Our group at the Universidade Paulista-UNIP, in São Paulo, Brazil, focuses on collecting plants from the Amazon rain forest (Manaus, AM) and from Atlantic Forest (Iguape, Cananéia e Registro, SP). The university continuously provides local facilities - including laboratories, boats, and personnel - in both regions, as well as a com- plete infrastructure capable of testing approximately 500 extracts per year in the main laboratory located in São Paulo.

The establishment of a bank of extracts has been a priority since the beginning of the project. Special attention, investment and technical support have been spent in selecting and processing plant material. For that reason, today the laboratory has developed one of the most standardized banks of extracts, composed of plants native to the Amazon and Atlantic Forests. Due to the enormous biovidersity of this region, sample collection strategies had to be rigorously defined in order to create a well-established bank of extracts. Plant collection can be based on native traditional knowledge, chemotaxonomic information, or random prospection, i.e., collection of all possible plant samples containing flower or fruit. The random approach is easier in the field, where the plants are collected. Special attention is given to plants in the reproductive cycle, which allow for better taxonomic identification. However, there are advantages and disadvantages to this approach. The advantage is that collecting a good variety of species certainly adds value to the bank of extracts. Conceivably, a wide variety of plants may lead to a wide variety of pharmacological activity and phytochemicals, especially once the random collection contains both the plants used as medicine by traditional communities and the plants that are not traditionally used but which may still contain active compounds. The downside is the higher investment needed to perform random collections, due to the diversity of natural resources. Effort and significant resources are necessary to process the plants, and more frequent expeditions are needed to detect flowering of the plants on a regular basis. The high number of species to be identified, processed and tested requires well-established and dedicated technical and scientific personnel.

An important issue in natural product drug discovery in Brazil is the regulatory laws that control the access to biodiversity. Bioprospection in Brazil is regulated by strict laws based on the Convention of Biodiversity. The law basically regulates access to the Brazilian genetic patrimony and allows for its bioprospection. Any Brazilian citizen or foreigner who desires to bioprospect in Brazil must apply for one license to access the biodiversity and collect material, and another to do the biological research. Foreigners must have a Brazilian collaborator. Local authorities are trying to establish more effective systems to support the important research efforts developed by established and prospective scientific institutions in the country, allowing more widespread, and at the same time controlled, bioprospection. Foreign support to develop meaningful steps for finding new drugs is still a necessity, as the Bra- 
zilian authorities and private industries do not have the tradition of investing in basic research. Meanwhile, tapping the Brazilian biodiversity is a slow and painstaking endeavor, and the results are slowly showing their potential.

The UNIP bank of extracts has approximately 2,000 aqueous and organic extracts obtained from different parts of plants, or from whole plants, depending on biomass availability. Most of them were collected in the Amazon Rain Forest, using a laboratory boat especially equipped for the present project.

After collection, the initial plant processing, such as cleaning insects and other species from the material and separating the organs (leaves, stem, fruits, flowers, wood, roots, barks, etc.), is usually conducted inside the boat, as are the initial taxonomic identifications up to the level of gender, whenever possible.

The crude plant material is brought to São Paulo to be processed. Plant organs are separated and then completely dried in an air-circulating stove at $40{ }^{\circ} \mathrm{C}$. The material is ground in a hammer-mil. The ground material is placed in glass percolators and an organic extract is obtained through initial maceration with equal volumes of dichloromethane and methanol, followed by maceration with water with the same plant material previously used, resulting in two extracts from each plant. Solvents from the organic extract are evaporated with a rotary evaporator and water from aqueous extracts is lyophilized. The organic and aqueous dry extracts are kept in freezers at $-20{ }^{\circ} \mathrm{C}$ until use.

Two in vitro biological assays were selected to study the extracts: 1) a cytotoxic assay based on human cancercell lines, and 2) an antibacterial assay performed on four resistant bacteria (Staphylococcus aureus, Enterococcus faecalis, Pseudomonas aeruginosa and Escherichia coli). As both techniques are conduced in 96-well plates, a large number of samples can be tested in a short period of time, and only a small amount of each sample is required. This allows for collection of small samples from each plant and for the collection of a wide range of species on each boat trip into the forests. Recollection from a specific plant is only required when extracts show activity in the screening assay, and further identification studies are anticipated.

The antitumoral screening assays performed in the Laboratório de Extração at UNIP are directed against six human cancer cell lines provided by the National Cancer Institute (DTP/NCI/NIH/USA). The cancer cell lines were chosen according to the most prevalent malignant diseases occurring in Brazil ${ }^{20}$.The assay is briefly described as follows ${ }^{21}$. Suspensions of breast, prostate, lung, colon, central nervous system, and leukemia cell lines are prepared at concentrations of 10,000,7,500, 7,500, 15,000, 15,000 and 200,000 cells per well, respectively. After one day incubation, samples of extracts are added at an initial concentration of $100 \mu \mathrm{g} / \mathrm{mL}$. Microplates are incubated for 48 $\mathrm{h}$ before being analyzed by the SRB colorimetric method. Analysis is carried out in a microplate reader at $515 \mathrm{~nm}$. The percentage of lethality is obtained for each sample, and the extracts that are able to kill $15 \%$ of the cell lines are chosen for fractionation. The fractions are re-evaluated against the cancer cell lines so that active ones are identified and subjected to further fractionation. This procedure continues until the active substances are isolated. The isolated substances are identified using traditional techniques, such as UV, NMR, MS and IR spectrometer analysis, on a collaborative basis. Fractionations are being done now with some of the active extracts.

The antibacterial assay is performed against the abovementioned four strains of bacteria, obtained from the American Type Culture Collection. Briefly, suspensions with defined concentrations of bacteria are prepared and transferred to the microplate wells. The extracts are added to the corresponding wells at a single concentration of 100 $\mathrm{mg} / \mathrm{mL} .{ }^{22}$ After $24-\mathrm{h}$ incubation, the extracts are evaluated and the active ones, i.e., those able to inhibit bacterial growth, are subjected to the analysis of minimal inhibitory concentration (MIC) and minimal bactericidal concentration (MBC). Extracts showing MIC d•200 mg/mL are selected for further bioguided fractionation.

The Laboratório de Extração has now screened over 1,220 plant extracts against the six human cancer cell lines and four bacteria, totaling 12,200 tests. From the initial screening processes, 72 extracts showed significant activity against at least one of the cancer cell lines and 50 extracts showed antibacterial activity against one or more bacteria used in the assay at the initial concentration of 100 $\mathrm{mg} / \mathrm{mL}$. Those active extracts were fractionated using solid phase extraction syringes and a gradient of solvents comprised of dichloromethane, acetonitrile, ethanol, methanol and water. The fractions were tested in the biological assays at a concentration of $100 \mu \mathrm{g} / \mathrm{mL}$. Results are currently being analyzed and subjected to phytochemical evaluation in order to further detect the main classes of compounds responsible for the observed biological activity. The compounds within each active fraction should be isolated and identified. Other biological assays should be established in order to evaluate and determine the mechanisms underlying the antitumor or the antibacterial drug activity.

The optimization of drug discovery using screening techniques and high throughput analysis, as well as the advancement of techniques involving spectrometry, led to the identification of tens of thousands of active marine and terrestrial natural products, some of which, including 
topotecan, irinotecan and camptothecin from terrestrial sources and bryostatin, dolastatin-10 and ecteinascidin 743 from marine sources, are now in clinical trial. Prospecting the Brazilian rain forests is challenging, but the possibility of new effective compounds supports current efforts in the search for new lead products. ${ }^{23-30}$

The encouraging results obtained from the screening project represent an important step towards the effective identification of active drugs against cancer and infectious diseases. Other assays are currently being evaluated and established to evaluate the potential activity of the plant extracts against a wide variety of common diseases. Intensive involvement of national and international researchers and laboratories in the systematic screening of active products is required, and will certainly lead to further introduction of more effective drugs to treat cancer and other diseases in the medical armamentarium.

\section{ACKNOWLEDGEMENTS}

The authors thank FAPESP (grant\#99/05904-6) and $\mathrm{NCI} / \mathrm{NIH} / \mathrm{USA}$ for the human cancer cell lines.

\section{RESUMO}

Younes RN, Varella AD, Suffredini IB. Descoberta de novos fármacos anti-tumorais e anti-bacterianos de extratos vegetais brasileiros através de screening em larga escala. Clinics. 2007;62(6):763-8.

Plantas são uma importante fonte de novos protótipos há pelo menos quatro décadas. A descoberta e introdução no mercado de paclitaxel, dos alcalóides da vinca, etoposídeo e muitos agentes antibacterianos têm servido de apoio ao desenvolvimento de programas de descobrimento de novos fármacos baseados em produtos naturais. Produtos naturais foram recentemente redescobertos como importante ferramenta na descoberta de novos fármacos devido às estruturas moleculares complexas capazes de interagir com alvos em células de mamíferos. A flora brasileira, a mais rica do mundo, tornou-se um importante sítio para 
prospecção de novos protótipos em decorrência da riqueza de espécies vegetais relacionada a uma possível diversidade química. Programas de triagem têm sido introduzidos no Brasil contrapondo a devastação de florestas relacionadas a atividades rurais, extrativismo madeireiro e mineral. Ensaios em larga escala permitem a análise de um grande número de amostras em um tempo relativamente pequeno, e pode ser considerado como o método mais eficaz para a descoberta de novos fármacos a partir de plantas. Dados atualizados relativos a programas de triagem que objetivam a identificação de novos protótipos antitumorais e antibacterianos são comentados.

UNITERMOS: Biodiversidade."Screening”. Produtos Naturais. Floresta Amazônica. Mata Atlântica

\section{REFERENCES}

1. Jemal A, Siegel R, Ward E, Murray T, Xu J, Thun MJ. Cancer statistics, 2007. CA Cancer J Clin. 2007;57:43-66.

2. Le Chevalier T, Lynch T. Adjuvant treatment of lung cancer: current status and potential applications of new regimens. Lung Cancer.2004; 46(Suppl 2):S33-9.

3. Singh N, Leger MM, Campbell J, Short B, Campos JM. Control of vancomycin-resistant Enterococci in the neonatal intensive care unit. Infect Control Hosp Epidemiol. 2005;26:646-9.

4. Birtles A, Virgincar N, Sheppard, CL, Walker RA, Johnson AP, Warner $\mathrm{M}$, et al. Antimicrobial resistance of invasive Streptococcus pneumoniae isolates in a British district general hospital: the international connection. J Med Microbiol. 2004;53:1241-6.

5. Loureiro MM, de Moraes BA, Mendonça VL, Quadra MR, Pinheiro GS, Asensi MD. Pseudomonas aeruginosa: study of antibiotic resistance and molecular typing in hospital infection cases in a neonatal intensive care unit from Rio de Janeiro City, Brazil. Mem Inst Oswaldo Cruz. 2002;97:387-94.

6. Tenssaie ZW. Multiple antimicrobial resistance in gram negative bacilli isolated from clinical specimens, Jimma Hospital, southwest Ethiopia. Ethiop Med J. 2001;39:305-12

7. Cragg GM, Newman DJ, Snader KM. Natural products in drug discovery and development. J Nat Prod. 1997;60:52-60.

8. Newman DJ, Cragg GM, Snader KM. Natural products as sources of new drugs over the period 1981-2002. J Nat Prod. 2003;66:1022-37.

9. Paterson I, Anderson A. The renaissance of natural products as drug candidates. Science. 2005;310:451-3.

10. Martin YC, Critchlow RE. Beyond mere diversity: tailoring combinatorial libraries for drug discovery. J Comb Chem. 1999;1:3245 .
11. van Der Heijden R, Jacobs DI, Snoeijer W, Hallard D, Verpoorte R. The Catharanthus alkaloids: pharmacognosy and biotechnology. Curr Med Chem. 2004;11:607-28

12. Heywood VH. Flowering plants of the world. New York: Oxford University Press; 1993.

13. Wilson EO, Peter FM. Biodiversity. Washington, DC: National Academic Press; 1988.

14. Brazil Ministério do Meio Ambiente, dos Recursos Hídricos e da Amazonia Legal. Primeiro relatório nacional para a convenção sobre diversidade biológica. Ministério do Meio Ambiente: Brasília, 1998.

15. Dossiê Mata Atlântica. Projeto monitoramento participativo da mata Atlântica. Capobianco JPR (Editor), Instituto Socioambiental; Rede de ONGs Mata Atlântica, Sociedade Nordestina de Ecologia. Ipsis Gráfica e Editora: São Paulo, 2001.

16. Myers N, Mittermeier RA, Mittermeier CG, Fonseca GAB, Kent J. Biodiversity hotspots for conservation priorities. Nature. 2000;403:8538.

17. Dewick PM. In: Evans WC. Trease and Evans' pharmacognosy. WB London: Saunders; 1996. p.409-425.

18. Pezzuto JM. Plant-derived anticancer agents. Biochem Pharmacol. 1997;53:121-33.

19. Balunas MJ, Kinghorn AD. Drug discovery from medicinal plants. Life Sci. 2005;78:431-41.

20. DATASUS/Brazil. www.datasus.gov.br. Accessed in November 2005. Site in Portuguese.

21. Monks A, Scudiero D, Skehan P, Shoemaker R, Paull K, Vistica D, et al. Feasibility of a high-flux anticancer drug screen using a diverse panel of cultured human tumor cell lines. J Natl Cancer Inst. 1991;83:757-66. 
22. Suffredini IB, Sader HS, Gonçalves AG, Reis AO, Gales AC, Varella $\mathrm{AD}$, et al. Screening of antibacterial extracts from plants native to the Brazilian Amazon Rain Forest and Atlantic Forest. Braz J Med Biol Res. 2004;37:379-84.

23. Kim J, Park EJ. Cytotoxic anticancer candidates from natural resources Curr Med Chem Anti-Canc Agents. 2002;2:485-537.

24. Baldwin EL, Osheroff N. Etoposide, topoisomerase II and cancer. Curr Med Chem Anti-Canc Agents. 2005;5:363-72.

25. Harrigan GG, Goetz GH. Chemical and biological integrity in natural products screening. Comb. Chem. High. Throughput Screen. 2005;8: 529-34.

26. Suffredini IB, Paciencia ML, Varella AD, Younes RN. In vitro cytotoxic activity of Brazilian plant extracts against human lung, colon and CNS solid cancers and leukemia. Fitoterapia. 2007;78:223-6.
27. Suffredini IB, Paciencia ML, Varella AD, Younes RN. Antibacterial activity of Brazilian Amazon plant extracts. Braz J Infect Dis. 2006;10:400-2.

28. Suffredini IB, Paciencia ML, Nepomuceno DC, Younes RN, Varella AD. Antibacterial and cytotoxic activity of Brazilian plant extractsClusiaceae. Mem Inst Oswaldo Cruz. 2006;101:287-90.

29. Suffredini IB, Varella AD, Younes RN. Cytotoxic molecules from natural sources: tapping the Brazilian biodiversity. Anticancer Agents Med Chem. 2006;6:367-79.

30. Suffredini IB, Paciencia ML, Varella AD, Younes RN.: In vitro prostate cancer cell growth inhibition by Brazilian plant extracts. Pharmazie. 2006;61:722-4. 